Venceslau, A. '; Corrêa, H.L. ${ }^{2}$; Gioso, M.A. ${ }^{3}$

\section{1 - Restaurações estéticas: nova alternativa em tratamentos odontológicos}

1- Médico Veterinário autônomo - Odontovet, Sâo Paulo-SP

2- Mestre em Cirurgia da Faculdade de Medicina Veterinária e Zootecnia da Universidade de São Paulo, São Paulo-SP - Odontovet, São Paulo-SP

3- Departamento de Cirurgia da Faculdade de Medicina Veterinária e Zootecnia da Universidade de São Paulo, São Paulo-SP

Freqüentemente encontradas na clínica de pequenos animais, as fraturas dentárias podem apresentar-se desde simples, com danos apenas ao esmalte ou dentina e sem comprometimento pulpar, até complicadas, com implicações da polpa e com grande perda estética e funcional. As restaurações com resinas e uso de pino intra-radicular visam devolver forma, função e também estética aos dentes acometidos. Um paciente da raça Akita Americano, macho, um ano e seis meses, pesando $27 \mathrm{Kg}$, chegou à clínica com fratura dental em canino superior esquerdo (204) e em incisivo lateral superior esquerdo (203) ocorridas no dia anterior, ambas com exposição de tecido pulpar, provocadas por briga com outro animal. A fratura em incisivo ocasionou apenas pequena perda de cúspide, porém, em canino, a fratura levou a perda de aproximadamente metade da coroa clínica. Foi realizada na primeira sessão a pulpectomia total com colocação de MIC (medicação intracanal) a base de hidróxido de cálcio PA, restauração provisória em ionômero de vidro e indicado retorno em 20 dias para obturação e reconstrução coronal. Após 30 dias, o proprietário retornou, ocasião em que foi realizado o tratamento endodôntico convencional. No incisivo, foi utilizado material de restauraçào intermediário (hidróxido de cálcio em pasta) e restauração em resina composta fotopolimerizável, onde foi refeita a cúspide perdida na fratura. No dente canino, após a obturação, foi realizado o preparo do conduto para adaptação de pino intra-radicular. Após o condicionamento ácido, um pino intra-radicular de fibra de vidro foi cimentado com cimento resinoso e ajustado de acordo com o tamanho pretendido da coroa a ser restaurada. Uma vez que o pino fora fixado, procedeu-se à restauração em resina composta fotopolimerizável, sendo feita aplicação em camadas sucessivas. Concluída a restauração da coroa em resina, foi realizado o acabamento final com uso de brocas diamantadas de granulação fina e discos para polimento. A vantagem neste tipo de tratamento é que a restauraçào em resina composta é uma alternativa em tratamentos de dentes fraturados, já que nào compromete a estética, uma vez que a gama de cores e tonalidades das resinas existentes é bastante grande, embora ainda não padronizada para dentes de animais, que apresentam dentes muito mais claros e brancos que humanos. Apesar dos sistemas adesivos disponiveis oferecerem grande resistência e retentividade, podem não ser suficientes para suportar as cargas mastigatórias complexas (cizalhamento, traçăo e compressão) dos animais carnívoros. A utilizaçào do pino de fibra de vidro intra-radicular serve como suporte para a aplicação da resina em sua porção coronal, o que permite que seja devolvida a anatomia dental, além de favorecer a dissipação de tensões geradas através da raiz, já que suas propriedades mecânicas estão bastante próximas da estrutura dental, devolvendo funçào ao dente. A aplicação de técnicas que devolvam a forma, função e estética ao dente fraturado, também proporcionam uma satisfação muito grande por parte de proprietários, que percebem que a odontologia veterinária cada vez mais torna-se importante e toma lugar de destaque dentre as especialidades hoje oferecidas na profissão. 